\title{
Characterization of Spinach Germplasm for Resistance Against Two Races of Verticillium dahliae
}

\author{
Beiquan Mou', Steven J. Klosterman, Amy Anchieta, \\ and Elisabeth Wood \\ United States Department of Agriculture (USDA), Agricultural Research \\ Service, 1636 East Alisal Street, Salinas, CA 93905 \\ Krishna V. Subbarao \\ Department of Plant Pathology, University of California, Davis, clo U. S. \\ Agricultural Research Station, 1636 East Alisal Street, Salinas, CA 93905
}

Additional index words. Verticillium tricorpus, Verticillium isaacii, verticillium wilt, disease resistance, germplasm screening, spinach breeding

\begin{abstract}
Historically, wilt disease caused by Verticillium dahliae has not presented a problem in California spinach production because the crop is harvested well before the symptoms develop after the stem elongation (bolting) stage. However, infested spinach seeds introduce or increase inoculum in the soil for rotational crops such as lettuce. This investigation was designed to identify verticillium wilt-resistant accessions in the U.S. Department of Agriculture (USDA) spinach germplasm collection against races 1 and 2 of $V$. dahliae, and to examine seed transmission of the pathogen in different spinach genotypes. In a seed health assay of 392 accessions, 21(5.4\%) were positive for $V$. dahliae, and $153(39 \%)$ were positive for Verticillium isaacii. A total of 268 accessions plus nine commercial cultivars were then screened against one race 1 and two race 2 isolates from spinach in replicated greenhouse experiments. Disease incidence, severity, and seed transmission through plating on NP-10 medium and real-time quantitative polymerase chain reaction (qPCR) were assessed. There was wide variation among accessions in their response to $V$. dahliae with disease incidence ranging from $0 \%$ to $100 \%$. The two race 2 isolates differed in their virulence against spinach genotypes. Resistant accessions were identified against both races 1 and 2 . Recovery of $V$. dahliae from seeds plated on NP-10 medium and $q P C R$ results were highly correlated $(P=0.00014)$. Some accessions identified as resistant based on disease incidence showed little seed transmission of the pathogen. Even though lower wilt incidence and severity generally corresponded with lower seed transmission rates, there were exceptions $(r=0.52)$. Variation among plants within accessions was also observed. Nevertheless, the sources of resistance identified in this study are useful for spinach cultivar improvement.
\end{abstract}

Verticillium dahliae is a soilborne fungal pathogen that causes wilt diseases and devastating losses in many important crops (Klosterman et al., 2009). The resting structures

Received for publication 4 Sept. 2015. Accepted for publication 5 Oct. 2015 .

The work was funded in part by the California Leafy Greens Research Program, the California Department of Food and Agriculture Specialty Crop Block Grant Agreement SCB09023, and the USDA Specialty Crop Research Initiative Grant 2010-51181-21069.

We thank K. Maruthachalam, J. Tanaka, R. Marchebout, S. Baker, S. Camberos, A. E. Estrada, J. Mora, and D. Zendejas for their technical support and help. We also thank the USDA North Central Regional Plant Introduction Station, Iowa State University, Ames, IA, for providing seeds of the spinach germplasm collection for screening.

Mention of trade names or commercial products in this publication is solely for the purpose of providing specific information and does not imply recommendation or endorsement by the USDA. USDA is an equal opportunity provider and employer.

${ }^{1}$ Corresponding author. E-mail: beiquan.mou@ars. usda.gov. produced by $V$. dahliae, known as microsclerotia, can survive in soil for up to 14 years (Wilhelm, 1955), and in seed and plant debris for several years (Pegg and Brady, 2002). The pathogen can be dispersed through soil, seed, vegetative material, farm equipment, water, and air (Pegg and Brady, 2002). Two pathogenic races of $V$. dahliae have been identified in lettuce and tomato (Baergen et al., 1993; Hayes et al., 2011b; Vallad et al., 2006), and both of these races can be recovered from infested spinach (Spinacia oleracea L.) seeds (Short et al., 2014).

California accounts for $\approx 70 \%$ of the spinach production in the United States, valued at \$271 million in 2014 (NASS, 2014). Although verticillium wilt has not been perceived as a problem for California spinach growers because disease symptoms normally appear following the stem elongation (bolting) stage (du Toit et al., 2005), it is now apparent that infected spinach seeds introduce or increase inoculum levels in the soil for rotational crops of lettuce (Short et al., 2015) and also likely for artichoke, strawberry, etc. A seed health assay revealed that 68 of $75(91 \%)$ commercial seed lots produced in Denmark, Holland, New Zealand, and the United States were infested with $V$. dahliae with pathogen recovery rates ranging from $0.3 \%$ to $84.8 \%$ (du Toit et al., 2005). Similarly, Duressa et al. (2012) recorded seed infestation rates of up to $85 \%$ in commercial spinach seed lots. Spinach seeding rates are exceptionally high in California with 8.6 to 9.9 million seeds planted per hectare for the popular baby leaf production (Koike et al., 2011). The introduction of a large amount of infected seeds coupled with the steep increase in spinach production in central coastal California since the 1990s has coincided with the appearance and spread of verticillium wilt on lettuce, first discovered in the region in 1995 (Atallah et al., 2011; Subbarao et al., 1997). Fumigation with methyl bromide or other chemicals is effective, but is neither registered for use nor economically feasible for lettuce (Atallah et al., 2011). Crop rotation has limited practicality in the control of the disease, since most of the potential alternate crops are also susceptible to verticillium wilt.

The most economical means of verticillium wilt management is through host resistance. Resistance $(R)$ genes against $V$. dahliae race 1 have been identified in cotton, sunflower, tomato, and lettuce (Fick and Zimmer, 1974; Hayes et al., 2011c; Schaible et al., 1951; Zhang et al., 2011). Crosspathogenicity of the race 1 isolates on different hosts, such as tomato and lettuce, has been demonstrated (Maruthachalam et al., 2010). So far, only partial resistance to race 2 has been found in tomato (Baergen et al., 1993) and lettuce (Hayes et al., 2011b).

One recent study examined resistance to verticillium wilt in spinach (VillarroelZeballos et al., 2012). The authors screened 120 spinach accessions from the USDA spinach collection and 10 commercial cultivars against verticillium wilt. No accession was immune (completely resistant) to the disease, and there did not appear to be qualitative or major gene resistance to verticillium wilt in the germplasm screened. Despite commercial fresh-market spinach crops being unaffected by verticillium wilt, seed from resistant cultivars may reduce the quantity of $V$. dahliae microsclerotia introduced into the soil when the crop is planted and increase seed yields in spinach seed producing regions.

There is also concern about the introduction of race 2 isolates of the pathogen on spinach seeds, as disproportionate numbers of race 2 isolates of $V$. dahliae have been identified among isolates recovered from infested spinach seed. A race-specific PCR assay identified $96 \%$ of isolates as race 2 from among the $340 \mathrm{~V}$. dahliae isolates recovered from spinach seeds produced in Chile, Denmark, the Netherlands, and the United States (Short et al., 2014). With the deployment of race 1 resistance in lettuce cultivars (Hayes et al., 2011a), it is expected that the proportion of race 2 will increase in California soils under the genetic selection 
pressure. For this reason, identification and development of spinach germplasm with resistance to race 2 isolates are necessary. Except for the 120 accessions evaluated by Villarroel-Zeballos et al. (2012), the majority of the USDA spinach germplasm collection has remained untested for resistance to verticillium wilt. This investigation was undertaken to: 1) identify verticillium wiltresistant genotypes in the USDA spinach germplasm collection; 2) observe the responses of spinach varieties to race 1 and race 2 isolates of $V$. dahliae; and 3 ) examine the seed transmission of $V$. dahliae in spinach genotypes.

\section{Materials and Methods}

Plant materials. Seeds of the USDA spinach germplasm collection were provided by the North Central Regional Plant Introduction Station, Iowa State University, Ames, IA. Twenty seeds from each of the accessions were plated on NP-10 medium in petri dishes as previously described (Maruthachalam et al., 2013), and following incubation on laboratory benches for $10 \mathrm{~d}$ $\left(24 \pm 1^{\circ} \mathrm{C}\right)$, examined under a microscope for morphological characteristics typical of Verticillium species (Inderbitzin et al., 2011). A total of 21 accessions were positive for $V$. dahliae and were excluded from the experiment. The 120 accessions used in a previous screening experiment (Villarroel-Zeballos et al., 2012) were also excluded from the current investigation. The remaining 268 accessions plus 9 commercial cultivars were included in a preliminary screening in the greenhouse using race 2 isolate So 923 with three inoculated replications. From this initial screen, 12 putative resistant, 2 susceptible, and 2 commercial cultivars (Tarpy and Polar Bear) were selected for further testing, which also includes four resistant accessions [PI 163309, PI 175931, PI 261789, and PI 648945 (Ames 26243)] identified in a previous study (Villarroel-Zeballos et al., 2012). In all tests, genotypes were planted in four inoculated replications and one uninoculated replication in a greenhouse in a randomized complete block design. In each replication, eight seeds of each accession were planted in Sunshine Plug 5 Growing Mix (Sun Gro Horticulture, Agawam, MA) in plastic transplanting trays $(128$ cells, $3 \times 3 \times 5 \mathrm{~cm}$ in length $\times$ width $\times$ height) in a greenhouse in the winter to control daylength with supplemental lighting. All tests were repeated once to confirm the results.

Pathogen inoculations. Two race 2 isolates from spinach, So 923 and So 925 , and a race 1 isolate So 302 from spinach were used to inoculate spinach plants. Seedlings were inoculated at 3, 4, and 5 weeks after sowing by saturating the soil in each plug tray well with a $3-\mathrm{mL}$ suspension containing $2 \times 10^{6}$ conidia/mL in sterile, distilled water. Seedlings were incubated for another week after the last inoculation and then transplanted into $0.5-\mathrm{L}(16 \mathrm{oz})$ foam-insulated cups filled with a pasteurized sand : potting soil mixture
$(3: 1, \mathrm{v} / \mathrm{v})$. One week after transplanting, daylength was extended to $19 \mathrm{~h} \cdot \mathrm{d}^{-1}$ by supplemental lighting to promote bolting, as symptoms of verticillium wilt on spinach mainly develop after the bolting stage.

Disease evaluations. Starting from 3 weeks after the last inoculation, severity of symptoms were rated weekly using a scale of 0 to $4: 0=$ no symptoms, $1=$ lower leaves with patches of yellow areas or wilting, $2=$ middle leaves with patches of yellow areas or wilting, 3 = upper leaves with patches of yellow areas or wilting, and $4=$ all leaves died. After the final rating, roots were washed free of sand and cut longitudinally to evaluate the disease as the percent brown discoloration of vascular tissue in the roots, crown, and lower stem, characteristic of verticillium wilt. The growth period (from planting to death of all leaves) of the inoculated plants was compared with the uninoculated control. To confirm the presence of the pathogen, $V$. dahliae was reisolated from diseased tissue by placing roots, crown, and lower stems on NP-10 medium following surface sterilization (1\% bleach solution for $1 \mathrm{~min})$ and examined microscopically for the development of conidiophores and/or microsclerotia of $V$. dahliae.

Seed transmission. To examine the seed transmission of the pathogen, mature seeds from each plant were harvested separately and assayed for $V$. dahliae by plating 20 seeds on NP-10 medium and incubating on laboratory benches for $10 \mathrm{~d}$. The seeds were then observed under a microscope for microsclerotia and/or conidiophores and conidial characteristics of $V$. dahliae. The seeds were also analyzed for the presence of $V$. dahlia with a real-time qPCR assay by using primers derived from $\beta$-tubulin of $V$. dahliae (Duressa et al., 2012). All of the qPCR assays were performed as described previously (Duressa et al., 2012) with SYBR green dye and $\beta$-tubulin standard curves for copy number calculation, with the exception that only 20 seeds per sample were ground for testing in the current study.

Statistical analysis. The highest weekly disease severity ratings for each plant were used in the statistical analysis. Percentage data of diseased plants (incidence) and seed infection (determined by NP-10 test) were subjected to $\sin ^{-1} \cdot \sqrt{Y}$ transformation (Steel and Torrie, 1980) before being analyzed by analysis of variance using the general linear models procedure of JMP Version 10 (SAS Institute, Cary, NC). Genotype was considered a fixed effect with replication as a random effect. For comparisons among genotypes, least significant differences were calculated with a Type $I(\alpha)$ error rate of $P=$ 0.05 . Correlation and regression analyses of seed infection and qPCR data were also carried out by using the Fit $\mathrm{Y}$ by $\mathrm{X}$ function of JMP.

\section{Results}

The race 2 isolate So 923 of $V$. dahliae was used in the preliminary screening of 268 accessions and 9 commercial cultivars to select 12 putative resistant accessions for further testing. All commercial cultivars tested were susceptible to the disease caused by isolate So 923 (data not shown). Two of the commercial cultivars, Tarpy and Polar Bear; two susceptible accessions, PI 648942 and PI 648948; and four resistant accessions from a previous screening of the germplasm collection (Villarroel-Zeballos et al., 2012) were included as controls in the subsequent tests after the preliminary screening. There was a wide range of variation among genotypes in response to inoculations with the $V$. dahliae isolates (Tables 1 and 2). Disease incidence ranged from $0 \%$ to $100 \%$ and severity varied from 0 to 3 .

One accession from the Netherlands, PI 303138 , showed no disease $(0 \%$ incidence and mean severity of 0 ) when inoculated with the race 2 isolate So 923 (Table 1). Accessions PI 176774, PI 179042, NSL 6092, and NSL 6097 also exhibited low disease incidence and severity in response to isolate So 923 . In contrast, the susceptible controls (PI 648942 and PI 648948) and cultivars (Polar Bear and Tarpy) all had high levels of disease symptoms (Table 1).

Against another race 2 isolate So 925, PI 303138 exhibited symptoms, with $35 \%$ and $25 \%$ incidence in Test 1 and 2, respectively (Table 1). No accession was immune to the disease caused by isolate So 925. PI 179588, NSL 6097, and NSL 81328 showed low disease incidence and severity. The three accessions also had low disease ratings when inoculated with So 923 .

Two spinach accessions, PI 303138 and NSL 6092, were identified that exhibited either no disease or low disease severity ratings in response to the race 1 isolate So 302. Accession PI 303138 showed no disease symptoms following inoculation with isolate So 302 (Table 2), similar to the response observed following inoculation with the race 2 isolate So 923 (Table 1). NSL 6092 also displayed low disease incidence and severity ratings against these isolates (Table 2). In contrast, the susceptible controls and cultivars exhibited high disease ratings (Table 2).

The use of qPCR is often employed to analyze quantities of fungal pathogens in planta (Klosterman, 2012). In this study, there was a significant correlation $(P=$ $0.00014)$ between quantification cycle $(\mathrm{Cq})$ values obtained by qPCR detection of the $\beta$-tubulin fragment from $V$. dahliae (pathogen DNA copy number) and percent seed infected with $V$. dahliae from 20 spinach cultivars or accessions tested (Fig. 1).

The percentage of seed infected with $V$. dahliae as determined by plating seeds on NP-10 medium and pathogen DNA copy number derived from qPCR of the $V$. dahliae $\beta$-tubulin target are presented in Table 3 . These values are representative of two independent measures of the pathogen transmission through seeds. When inoculated with the race 2 isolate So 923 , the accessions PI 176774, PI 179042, and NSL 6097 showed little seed transmission of the pathogen. 
Table 1. Mean disease incidence and severity for selected accessions of the U.S. Department of Agriculture spinach germplasm collection and commercial cultivars in repeated tests inoculated with two Race 2 isolates of Verticillium dahliae So 923 and So 925 from spinach. Means with the same letter in a column are not significantly different at $P<0.05$ using least significant difference test.

\begin{tabular}{|c|c|c|c|c|c|c|c|c|c|}
\hline \multirow[b]{3}{*}{ Genotype } & \multirow[b]{3}{*}{ Origin } & \multicolumn{4}{|c|}{ So 923} & \multicolumn{4}{|c|}{ So 925} \\
\hline & & \multicolumn{2}{|c|}{ Incidence $(\%)$} & \multicolumn{2}{|c|}{ Severity } & \multicolumn{2}{|c|}{ Incidence $(\%)$} & \multicolumn{2}{|c|}{ Severity } \\
\hline & & Test 1 & Test 2 & Test 1 & Test 2 & Test 1 & Test 2 & Test 1 & Test 2 \\
\hline PI 648948 & China & $90.5 \mathrm{a}$ & $91.7 \mathrm{a}$ & $2.7 \mathrm{a}$ & $3.0 \mathrm{a}$ & $92.9 \mathrm{ab}$ & $90.0 \mathrm{a}$ & $2.7 \mathrm{ab}$ & $2.7 \mathrm{ab}$ \\
\hline Tarpy & Enza & $61.1 \mathrm{ab}$ & 31.7 cde & $3.0 \mathrm{a}$ & $2.8 \mathrm{ab}$ & 75.0 abcd & $61.0 \mathrm{abcd}$ & $2.9 \mathrm{ab}$ & $2.3 \mathrm{abc}$ \\
\hline Polar Bear & Rijk Zwaan & $47.2 \mathrm{bc}$ & $63.5 \mathrm{bcd}$ & $2.6 \mathrm{a}$ & $2.8 \mathrm{ab}$ & 58.4 bcdef & $72.9 \mathrm{ab}$ & $2.6 \mathrm{ab}$ & $2.7 \mathrm{ab}$ \\
\hline PI 175931 & Turkey & $36.1 \mathrm{bcd}$ & $61.3 \mathrm{bcd}$ & $2.4 \mathrm{ab}$ & $1.8 \mathrm{abcd}$ & 70.2 abcde & $0.0 \mathrm{~h}$ & $2.1 \mathrm{ab}$ & $0.0 \mathrm{f}$ \\
\hline NSL 81328 & Maryland, United States & 33.3 bcde & $0.0 \mathrm{~g}$ & $0.5 \mathrm{~cd}$ & $0.0 \mathrm{e}$ & 19.7 defg & $10.4 \mathrm{fgh}$ & $2.0 \mathrm{ab}$ & $0.6 \mathrm{ef}$ \\
\hline PI 648942 & China & 31.0 bcde & $77.8 \mathrm{ab}$ & $1.7 \mathrm{abc}$ & $2.6 \mathrm{ab}$ & $100.0 \mathrm{a}$ & $73.2 \mathrm{abc}$ & $2.9 \mathrm{ab}$ & $2.8 \mathrm{a}$ \\
\hline PI 648945 & China & 27.8 bcde & $63.5 \mathrm{bcd}$ & $1.9 \mathrm{abc}$ & $1.9 \mathrm{abcd}$ & $65.1 \mathrm{bcdef}$ & 31.3 defg & $1.8 \mathrm{bc}$ & 1.4 bcde \\
\hline PI 181923 & Syria & 26.4 bcde & $25.0 \mathrm{efg}$ & $1.5 \mathrm{abcd}$ & $0.6 \mathrm{de}$ & 45.9 cdef & $0.0 \mathrm{~h}$ & $2.5 \mathrm{ab}$ & $0.0 \mathrm{f}$ \\
\hline PI 204735 & Turkey & 19.4 bcde & $15.3 \mathrm{efg}$ & $1.0 \mathrm{bcd}$ & $1.0 \mathrm{de}$ & $25.0 \mathrm{fg}$ & $16.1 \mathrm{fgh}$ & $1.3 \mathrm{c}$ & $2.3 \mathrm{abc}$ \\
\hline NSL 6087 & New York, United States & 16.7 bcde & 28.9 def & $1.7 \mathrm{abc}$ & $1.9 \mathrm{abcd}$ & 28.6 cdefg & 59.5 bcde & $3.0 \mathrm{a}$ & $2.1 \mathrm{abcd}$ \\
\hline NSL 6097 & Minnesota, United States & $16.7 \mathrm{cde}$ & $4.2 \mathrm{fg}$ & $0.3 \mathrm{~cd}$ & $1.0 \mathrm{de}$ & $0.0 \mathrm{~g}$ & $11.3 \mathrm{fgh}$ & $0.0 \mathrm{~d}$ & $1.0 \mathrm{cdef}$ \\
\hline PI 179588 & Belgium & $16.7 \mathrm{cde}$ & 21.7 cdef & $0.7 \mathrm{~cd}$ & $3.0 \mathrm{a}$ & $12.5 \mathrm{fg}$ & $4.2 \mathrm{gh}$ & $2.0 \mathrm{abc}$ & $0.8 \mathrm{def}$ \\
\hline PI 171861 & Turkey & $14.3 \mathrm{cde}$ & $12.2 \mathrm{efg}$ & $1.2 \mathrm{bcd}$ & $2.0 \mathrm{abcd}$ & 42.9 cdef & $12.5 \mathrm{fgh}$ & $2.8 \mathrm{ab}$ & $1.0 \mathrm{cdef}$ \\
\hline PI 179042 & Turkey & $14.3 \mathrm{cde}$ & $0.0 \mathrm{~g}$ & $1.0 \mathrm{bcd}$ & $0.0 \mathrm{e}$ & $0.0 \mathrm{~g}$ & 43.8 bcdef & $0.0 \mathrm{~d}$ & $2.1 \mathrm{abcd}$ \\
\hline NSL 6092 & New York, United States & $8.3 \mathrm{de}$ & $0.0 \mathrm{~g}$ & $1.0 \mathrm{bcd}$ & $0.0 \mathrm{e}$ & 50.0 bcdef & 41.3 bcdef & $2.7 \mathrm{ab}$ & 1.7 abcde \\
\hline PI 167194 & Turkey & $0.0 \mathrm{e}$ & 30.0 cdef & $0.0 \mathrm{~d}$ & $2.7 \mathrm{ab}$ & 30.0 efg & $4.2 \mathrm{gh}$ & $1.0 \mathrm{~cd}$ & $0.5 \mathrm{e}$ \\
\hline PI 176774 & Turkey & $0.0 \mathrm{e}$ & $15.3 \mathrm{efg}$ & $0.0 \mathrm{~d}$ & $1.7 \mathrm{bcd}$ & 66.7 abcdef & 33.3 cdefg & $2.5 \mathrm{ab}$ & $2.0 \mathrm{abcd}$ \\
\hline PI 303138 & Netherlands & $0.0 \mathrm{e}$ & $0.0 \mathrm{~g}$ & $0.0 \mathrm{~d}$ & $0.0 \mathrm{e}$ & $34.8 \mathrm{cdef}$ & $25.0 \mathrm{efgh}$ & $2.8 \mathrm{ab}$ & $0.5 \mathrm{e}$ \\
\hline PI 163309 & India & - & 38.9 cde & - & $1.3 \mathrm{~cd}$ & $79.5 \mathrm{abc}$ & $19.3 \mathrm{fgh}$ & $2.9 \mathrm{ab}$ & $1.1 \mathrm{cdef}$ \\
\hline PI 261789 & France & - & 45.3 bcde & - & $2.4 \mathrm{abc}$ & $46.5 \mathrm{cdef}$ & $0.0 \mathrm{~h}$ & $3.0 \mathrm{a}$ & $0.0 \mathrm{f}$ \\
\hline
\end{tabular}

Table 2. Mean disease incidence and severity for selected accessions of the U.S. Department of Agriculture spinach germplasm collection and commercial cultivars in repeated tests inoculated with a race 1 isolate of Verticillium dahliae So 302 from spinach. Means with the same letter in a column are not significantly different at $P<0.05$ using least significant difference test.

\begin{tabular}{llccc}
\hline & \multicolumn{2}{c}{ Incidence (\%) } & & Severity \\
\cline { 2 - 3 } Genotype & Test 1 & Test 2 & Test 1 & Test 2 \\
\hline PI 648948 & $85.6 \mathrm{a}$ & $55.4 \mathrm{abcd}$ & $2.9 \mathrm{a}$ & $2.1 \mathrm{abcd}$ \\
PI 648942 & $76.2 \mathrm{a}$ & $78.5 \mathrm{a}$ & $2.9 \mathrm{a}$ & $2.3 \mathrm{abc}$ \\
PI 648945 & $72.6 \mathrm{ab}$ & $48.6 \mathrm{abcde}$ & $2.0 \mathrm{ab}$ & $2.0 \mathrm{abcd}$ \\
Tarpy & $70.2 \mathrm{abcd}$ & $51.1 \mathrm{abc}$ & $2.4 \mathrm{ab}$ & $2.8 \mathrm{a}$ \\
Polar Bear & $69.4 \mathrm{abc}$ & $74.3 \mathrm{ab}$ & $2.9 \mathrm{a}$ & $2.6 \mathrm{ab}$ \\
NSL 81328 & $66.7 \mathrm{abcd}$ & $0.0 \mathrm{~g}$ & $2.7 \mathrm{ab}$ & $0.0 \mathrm{f}$ \\
PI 261789 & $59.0 \mathrm{abcde}$ & $6.3 \mathrm{fg}$ & $2.5 \mathrm{ab}$ & $0.8 \mathrm{def}$ \\
PI 175931 & $52.4 \mathrm{abcdef}$ & $0.0 \mathrm{~g}$ & $2.5 \mathrm{ab}$ & $0.0 \mathrm{f}$ \\
PI 176774 & $52.4 \mathrm{abcdef}$ & $33.6 \mathrm{bcdef}$ & $1.7 \mathrm{abc}$ & $1.5 \mathrm{abcde}$ \\
NSL 6097 & $36.7 \mathrm{bcdefg}$ & $16.7 \mathrm{efg}$ & $1.8 \mathrm{ab}$ & $1.0 \mathrm{cdef}$ \\
PI 163309 & $36.2 \mathrm{bcdefg}$ & $16.4 \mathrm{efg}$ & $1.7 \mathrm{abc}$ & $0.8 \mathrm{def}$ \\
PI 179042 & $34.9 \mathrm{bcdefg}$ & $8.3 \mathrm{fg}$ & $1.7 \mathrm{abc}$ & $1.0 \mathrm{cdef}$ \\
PI 167194 & $33.3 \mathrm{bcdefg}$ & $38.9 \mathrm{bcdef}$ & $1.6 \mathrm{abc}$ & $1.3 \mathrm{bcdef}$ \\
PI 204735 & $27.8 \mathrm{cdefg}$ & $13.3 \mathrm{defg}$ & $1.8 \mathrm{ab}$ & $2.0 \mathrm{bcd}$ \\
PI 171861 & $4.2 \mathrm{fg}$ & $2.8 \mathrm{a}$ & $0.5 \mathrm{ef}$ \\
PI 179588 & $27.0 \mathrm{bcdefg}$ & $6.3 \mathrm{fg}$ & $3.0 \mathrm{a}$ & $0.8 \mathrm{def}$ \\
PI 181923 & $26.2 \mathrm{bcdefg}$ & $0.0 \mathrm{~g}$ & $1.3 \mathrm{bcd}$ & $0.0 \mathrm{f}$ \\
NSL 6092 & $24.6 \mathrm{defg}$ & $0.0 \mathrm{~g}$ & $0.3 \mathrm{~cd}$ & $0.0 \mathrm{f}$ \\
NSL 6087 & $11.1 \mathrm{fg}$ & $31.7 \mathrm{cdefg}$ & $2.0 \mathrm{ab}$ & $1.2 \mathrm{bcdef}$ \\
PI 303138 & $10.3 \mathrm{efg}$ & $0.0 \mathrm{~g}$ & $0.0 \mathrm{~d}$ & $0.0 \mathrm{f}$ \\
\hline
\end{tabular}

Against another race 2 isolate, So 925, accessions PI 175931, PI 261789, PI 303138, and PI 648945 exhibited low seed infection. Inoculated with a race 1 isolate So 302, the accessions PI 175931, PI 179042, PI 261789, PI 648942, NSL 6092, and NSL 6097 exhibited no seed infection on NP-10 medium and low pathogen copy number. Accessions PI 175931, PI 179042, PI 261789, and NSL 6097 showed little seed infection against both a race 1 and a race 2 isolate of $V$. dahliae.

\section{Discussion}

In a previous screening of the USDA spinach germplasm collection (VillarroelZeballos et al., 2012), 21 of 130 (16\%) accessions were reported as infested or infected with $V$. dahliae, Verticillium tricorpus, or Gibellulopsis nigrescens (formerly known as Verticillium nigrescens). Even though there was a major revision of the taxonomy of the genus Verticillium in 2011 (Inderbitzin et al., 2011), the authors used the names of the old taxa in their article (VillarroelZeballos et al., 2012). We have recently shown that (Short et al., 2015) the majority of isolates previously characterized as $V$. tricorpus actually belong to the newly erected species $V$. isaacii (Inderbitzin et al., 2011) and thus we report the results using the new taxonomy in this article. In our seed health assay of 392 accessions in the collection, $21(5.4 \%)$ were positive for $V$. dahliae and $153(39 \%)$ were positive for $V$. isaacii.
The seed infection of the 21 accessions demonstrated that these accessions were susceptible to $V$. dahliae and were therefore excluded from further testing. Verticillium isaacii is a weak pathogen on lettuce and artichoke and potentially can reduce the symptoms caused by $V$. dahliae on lettuce, probably due to the competition between the two species (Qin et al., 2008).

In the current study, no accession was completely resistant to the disease caused by both race 2 isolates. The results suggested that accessions may be resistant to the disease caused by one race 2 isolate, but susceptible to the disease caused by another race 2 isolate (Table 1). Thus, different race 2 isolates may differ in their virulence against spinach genotypes. It is important to use more than one isolate in resistance screening against a given race of the pathogen.

Although the $V$. dahliae isolates from spinach seeds are predominately race 2 , the pathogen population in the Salinas Valley is currently composed mostly of race 1 (Short et al., 2014). This is especially important considering that the Salinas Valley represents the major leafy vegetable production region in California, and that $V$. dahliae is crosspathogenic on most of these leafy vegetables (Short et al., 2015). Fresh market salad, bunched, and processing spinach crops are harvested 21-50, 32-62, and 48-90 d after planting in California, respectively (Koike et al., 2011). Verticillium dahliae hyphae can colonize spinach root cortical tissues both intra- and intercellularly by 2 weeks after inoculation (Maruthachalam et al., 2013). Although $V$. dahliae may not produce foliar symptoms in fresh-market spinach production fields, susceptible cultivars may increase the inoculum in the soil. Therefore, it is also desirable to have resistance to the disease caused by race 1 isolates of $V$. dahliae so that soil inoculum levels are not augmented with 
each new crop of spinach produced from infested seeds.

In $\mathrm{qPCR}$, the $\mathrm{Cq}$ value is inversely proportional to the amount of input DNA (lower $\mathrm{Cq}=$ higher amount of DNA). Thus, the highest percentage of seed infection, 30\% for PI 167194, was associated with the lowest Cq value (higher amount of pathogen DNA). Conversely, one of the two accessions with the lowest percent of seed infection (PI 175931), as determined by NP-10 plating, was associated with the highest $\mathrm{Cq}$ (lower amount of pathogen DNA). The finding that $\mathrm{Cq}$ values $>32$ were always associated with $<10 \%$ infected seed indicates that this particular value could be useful for screening purposes, to quickly identify those spinach accessions with lower amounts of pathogen DNA. In some instances, there is variable amount of pathogen DNA per individual seed when comparing multiple seed lots, as suggested previously (Duressa et al., 2012). The results of the qPCR analyses herein further support this conclusion. For instance, seeds collected from PI 163309 exhibited an infection percentage of $7 \%$ and a $\mathrm{Cq}$ value of 28.60. On the other hand, seeds collected from NSL 6087 were 19\% infected, with an associated $\mathrm{Cq}$ value of 30.43 .

The reduced leaf symptoms, as measured by disease incidence and severity in this

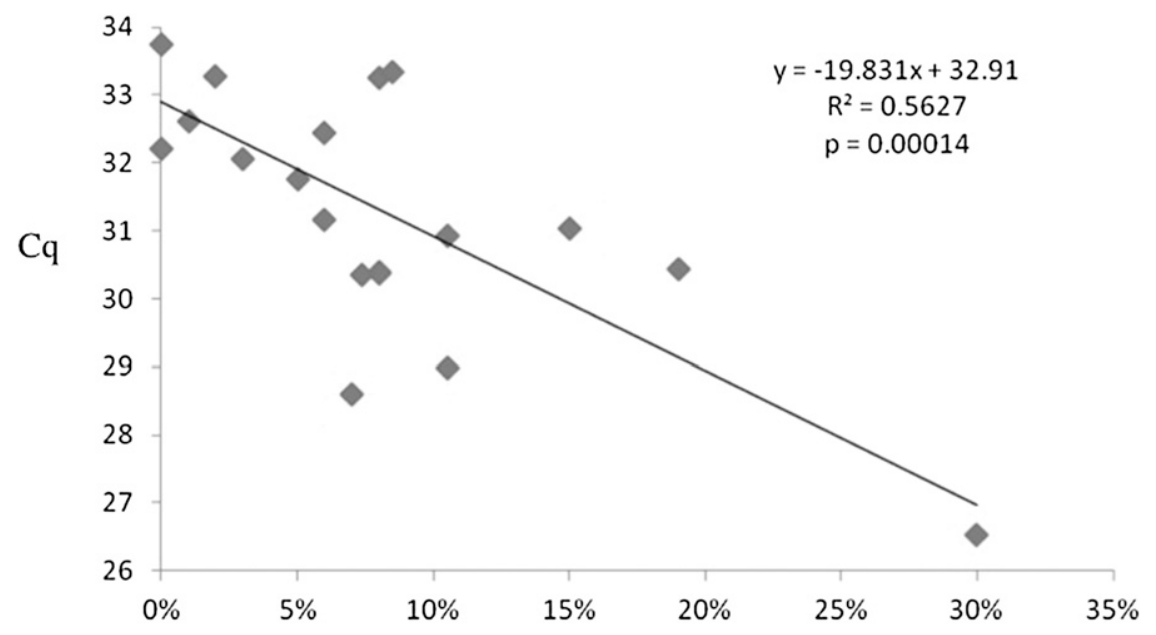

Seed Infected

Fig. 1. Correlation between quantification cycle $(\mathrm{Cq})$ values obtained by real-time quantitative polymerase chain reaction detection of the Verticillium dahliae $\beta$-tubulin gene and percent infected seed with $V$. dahliae from twenty spinach cultivars or accessions. A lower $\mathrm{Cq}$ value indicates increased DNA detection from the pathogen, $V$. dahliae. No outliers were removed. The $P$ value indicates a significant relationship between the two variables.

experiment, may help increase spinach seed yield. Perhaps even more importantly, elimination or reduction of spinach seed infection with $V$. dahliae may prevent or reduce the introduction of new inocula to regions where susceptible alternate host crops are produced, such as in central coastal California. Although lower disease incidence and severity generally corresponded to lower levels of pathogen seed transmission (correlation coefficient between percent disease incidence and results from NP-10 plating was 0.52), they were not always linked. For example, PI 303138 and PI 648945 had relatively high disease incidence when inoculated with the race 2 isolate So 925 , but showed low seed transmission as determined by NP-10 plating and qPCR analyses. In contrast, PI 303138 did not display disease symptoms in response to the race 2 isolate So 923 , but exhibited seed infection. Although reduced leaf symptoms may benefit spinach seed crops, low or no seed transmission of the pathogen is more important to the spinach production regions to prevent the introduction and/or increase of inocula in the soil. It may be possible to develop cultivars with reduced disease symptoms and a low level of pathogen transmission through seeds in a spinach breeding program.

Four resistant controls from a previous screening of the collection (VillarroelZeballos et al., 2012), PI 163309, PI 175931, PI 261789, and PI 648945 (Ames 26243), all displayed relatively high disease incidences and severity against the three isolates of $V$. dahliae in our tests (Tables 1 and 2). This discrepancy may be due to the different virulence of the isolates used in the screens. However, PI 175931 and PI 261789 showed almost no seed infection and pathogen DNA copy of a race 1 and a race 2 isolate (Table 3). PI 648945 also had little seed

Table 3. Mean seed infection percent (tested on NP-10 plates) and pathogen DNA copy number in seed [determined by real-time quantitative polymerase chain reaction (qPCR)] for selected accessions of the U.S. Department of Agriculture spinach germplasm collection and commercial cultivars inoculated with a race 1 isolate (So 302) and two race 2 isolates (So 923 and So 925) of Verticillium dahliae from spinach. Means of percentage was analyzed after $\sin ^{-1} \sqrt{Y}$ transformation of data. Means with the same letter in a column are not significantly different at $P<0.05$ using least significant difference test.

\begin{tabular}{|c|c|c|c|c|c|c|}
\hline \multirow[b]{2}{*}{ Genotype } & \multicolumn{2}{|c|}{ Race 2 So 923} & \multicolumn{2}{|c|}{ Race 2 So 925} & \multicolumn{2}{|c|}{ Race 1 So 302} \\
\hline & NP-10+\% & Copy no. ${ }^{z}$ & NP-10+\% & Copy no. & $\overline{\mathrm{NP}}-10+\%$ & Copy no. \\
\hline PI 648948 & $65.5 \mathrm{ab}$ & $883.1 \mathrm{a}$ & $12.5 \mathrm{abc}$ & $0.0 \mathrm{e}$ & $39.3 \mathrm{ab}$ & $392.0 \mathrm{bc}$ \\
\hline Polar Bear & $35.7 \mathrm{abc}$ & $78.3 \mathrm{~cd}$ & $14.6 \mathrm{abc}$ & $1.3 \mathrm{e}$ & $48.7 \mathrm{a}$ & $1,098.1 \mathrm{a}$ \\
\hline PI 648942 & $34.4 \mathrm{bcd}$ & $135.3 \mathrm{c}$ & $21.3 \mathrm{abc}$ & $0.0 \mathrm{e}$ & $0.0 \mathrm{~h}$ & $5.6 \mathrm{~d}$ \\
\hline PI 175931 & - & - & $0.0 \mathrm{c}$ & $1.5 \mathrm{e}$ & $0.0 \mathrm{~h}$ & $0.0 \mathrm{~d}$ \\
\hline PI 167194 & $25.0 \mathrm{bcde}$ & $7.4 \mathrm{~d}$ & $40.0 \mathrm{a}$ & $22.3 \mathrm{de}$ & $19.5 \mathrm{cde}$ & $268.8 \mathrm{~cd}$ \\
\hline NSL 6092 & $7.5 \mathrm{cdef}$ & $70.5 \mathrm{~cd}$ & $26.2 \mathrm{abc}$ & $308.3 \mathrm{~b}$ & $0.0 \mathrm{~h}$ & $1.6 \mathrm{~d}$ \\
\hline PI 204735 & $5.7 \mathrm{def}$ & $9.1 \mathrm{~d}$ & $22.4 \mathrm{abc}$ & $2.2 \mathrm{e}$ & $41.0 \mathrm{a}$ & $630.3 \mathrm{~b}$ \\
\hline NSL 81328 & $5.0 \mathrm{def}$ & $6.6 \mathrm{~d}$ & $33.3 \mathrm{ab}$ & $7.1 \mathrm{e}$ & 10.0 efgh & $78.3 \mathrm{~cd}$ \\
\hline PI 648945 & - & - & $0.0 \mathrm{c}$ & $2.0 \mathrm{e}$ & $3.2 \mathrm{fgh}$ & $10.6 \mathrm{~d}$ \\
\hline NSL 6087 & - & - & $36.3 \mathrm{ab}$ & $838.4 \mathrm{a}$ & $20.4 \mathrm{bcd}$ & $210.0 \mathrm{~cd}$ \\
\hline PI 179042 & $1.7 \mathrm{def}$ & $0.0 \mathrm{~d}$ & $19.2 \mathrm{abc}$ & 84.9 cde & $0.0 \mathrm{~h}$ & $2.3 \mathrm{~d}$ \\
\hline NSL 6097 & 0.4 ef & $5.3 \mathrm{~d}$ & $17.2 \mathrm{abc}$ & $163.0 \mathrm{~cd}$ & $0.0 \mathrm{~h}$ & $2.6 \mathrm{~d}$ \\
\hline
\end{tabular}

${ }^{\mathrm{z}}$ Copy no. refers to the pathogen DNA copy number as determined by qPCR, using a standard curve with the $V$. dahliae $\beta$-tubulin gene fragment as described (Duressa et al., 2012). 
transmission of the pathogen. The results confirm that these accessions have a certain level of resistance that prevented the pathogen from entering seeds.

This study completes the screening of all accessions of the USDA spinach germplasm collection against $V$. dahliae. Resistant accessions were identified, with resistance against both races 1 and 2 of $V$. dahliae. These accessions can be used as sources of resistance in spinach cultivar development. As in a previous germplasm screening (Villarroel-Zeballos et al., 2012), variation in disease symptoms was observed among plants within accessions. This is probably because all accessions in the USDA spinach germplasm collection are open-pollinated populations and heterogeneous in their genetic makeup. The results of this study provide an opportunity to further improve the resistance to $V$. dahliae in spinach through selection and breeding.

\section{Literature Cited}

Atallah, Z.K., R.J. Hayes, and K.V. Subbarao. 2011. Fifteen years of Verticillium wilt of lettuce in America's salad bowl: A tale of immigration, subjugation, and abatement. Plant Dis. 95:784-792.

Baergen, K., J. Hewitt, and D.S. Clair. 1993. Resistance of tomato genotypes to four isolates of Verticillium dahliae race 2. HortScience 28:833-836.

du Toit, L.J., M.L. Derie, and P. Hernandez-Perez. 2005. Verticillium wilt in spinach seed production. Plant Dis. 89:4-11.

Duressa, D., G. Rauscher, S.T. Koike, B. Mou, R.J. Hayes, K. Maruthachalam, K.V. Subbarao, and S.J. Klosterman. 2012. A real-time PCR assay for detection and quantification of Verticillium dahliae in spinach seed. Phytopathology 102:443-451.

Fick, G. and D.E. Zimmer. 1974. Monogenic resistance to Verticillium wilt in sunflowers. Crop Sci. 14:895-896.

Hayes, R.J., K. Maruthachalam, G.E. Vallad, S.J. Klosterman, I.S. Simko, L. Yaguang, and K.V. Subbarao. 2011a. Iceberg lettuce breeding lines with resistance to Verticillium wilt caused by race 1 isolates of Verticillium dahliae. HortScience 46:501-504.

Hayes, R.J., K. Maruthachalam, G.E. Vallad, S.J. Klosterman, and K.V. Subbarao. 2011b. Selection for resistance to Verticillium wilt caused by race 2 isolates of Verticillium dahliae in accessions of lettuce (Lactuca sativa L.). HortScience 46:201-206.

Hayes, R.J., L.K. McHale, G.E. Vallad, M.J. Truco, R.W. Michelmore, S.J. Klosterman, K. Maruthachalam, and K.V. Subbarao. 2011c The inheritance of resistance to Verticillium wilt caused by race 1 isolates of Verticillium dahliae in the lettuce cultivar La Brillante. Theor. Appl. Genet. 123:509-517.

Inderbitzin, P., R.M. Bostock, R.M. Davis, T Usami, H.W. Platt, and K.V. Subbarao. 2011 Phylogenetics and taxonomy of the fungal vascular wilt pathogen Verticillium, with the descriptions of five new species. PLoS One 6: e28341.

Klosterman, S.J. 2012. Real-time PCR for the quantification of fungi in planta, p. 121-131 In: M.D. Bolton and B.P.H.J. Thomma (eds.). Plant Fungal Pathogens: Methods and Protocols. Series: Methods in Molecular Biology, Volume 835. Humana Press, New York, NY.

Klosterman, S.J., Z.K. Atallah, G.E. Vallad, and K.V. Subbarao. 2009. Diversity, pathogenicity, and management of Verticillium species. Annu. Rev. Phytopathol. 47:39-62.

Koike, S.T., M. Cahn, M. Cantwell, S. Fennimore, M. Lestrange, E. Natwick, R.F. Smith, and E. Takele. 2011. Spinach production in California Publ. 7212. University of California, Agriculture and Natural Resources, Richmond, CA.

Maruthachalam, K., Z.K. Atallah, G.E. Vallad, S.J. Klosterman, R.M. Davis, and K.V. Subbarao. 2010. Molecular variation among isolates of Verticillium dahliae and polymerase chain reaction-based differentiation of races. Phytopathology 100:1222-1230.

Maruthachalam, K., S.J. Klosterman, A. Anchieta, B. Mou, and K.V. Subbarao. 2013. Colonization of spinach by Verticillium dahliae and effects of pathogen localization on the efficacy of seed treatments. Phytopathology 103:268280.

National Agricultural Statistics Service (NASS). 2014. 2 Sept. 2015. <http://quickstats.nass. usda.gov/\#C4809540-A736-3937-9DFE919007A7B190>.
Pegg, G. and B. Brady. 2002. Verticillium wilts. CAB International, Oxford, UK.

Qin, Q.-M., G.E. Vallad, and K.V. Subbarao. 2008. Characterization of Verticillium dahliae and $V$. tricorpus isolates from lettuce and artichoke. Plant Dis. 92:69-77.

Schaible, L., O.S. Cannon, and V. Waddoups. 1951. Inheritance of resistance to Verticillium wilt in a tomato cross. Phytopathology 41:986990.

Short, D.P.G., S. Gurung, S.T. Koike, S.J. Klosterman, and K.V. Subbarao. 2015. Frequency of Verticillium species in commercial spinach fields and transmission of $\mathrm{V}$. dahliae from spinach to subsequent lettuce crops. Phytopathology 105:80-90

Short, D.P.G., S. Gurung, K. Maruthachalam, Z.K. Atallah, and K.V. Subbarao. 2014. Verticillium dahliae race 2 -specific PCR reveals a high frequency of race 2 strains in commercial spinach seed lots and delineates race structure. Phytopathology 104:779-785.

Steel, R.G. and J.H. Torrie. 1980. Principles and procedures of statistics. A biometrical approach. 2nd ed. McGraw-Hill, New York, NY.

Subbarao, K.V., J.C. Hubbard, A.S. Greathead, and G.A. Spencer. 1997. Verticillium wilt, p. 26-27 In: R.M. Davis, K.V. Subbarao, R.N. Raid, and E.A. Kurtz (eds.). Compendium of lettuce diseases. The American Phytopathological Society, St. Paul, MN

Vallad, G.E., Q.-M. Qin, R.C. Grube, R.J. Hayes, and K.V. Subbarao. 2006. Characterization of race-specific interactions among isolates of Verticillium dahliae pathogenic on lettuce. Phytopathology 96:1380-1387.

Villarroel-Zeballos, M.I., C. Feng, A. Iglesias, L.J. du Toit, and J.C. Correll. 2012. Screening for resistance to Verticillium wilt in spinach and isolation of Verticillium dahliae from seed of spinach accessions. HortScience 47:12971303.

Wilhelm, S. 1955. Verticillium wilt of the strawberry with special reference to resistance. Phytopathology 45:387-391.

Zhang, Y., X. Wang, S. Yang, J. Chi, G. Zhang, and Z. Ma. 2011. Cloning and characterization of a Verticillium wilt resistance gene from Gossypium barbadense and functional analysis in Arabidopsis thaliana. Plant Cell Rpt. 30:20852096. 